\title{
Co-digestion of microalgae and primary sludge: Effect on biogas production and microcontaminants removal
}

\author{
Maria Solé-Bundó $^{\mathrm{a}}$, Marianna Garfí ${ }^{\mathrm{a}}$, Víctor Matamoros ${ }^{\mathrm{b}}$, Ivet Ferrer ${ }^{\mathrm{a}, *}$ \\ a GEMMA - Environmental Engineering and Microbiology Research Group, Department of Civil and Environmental Engineering, Universitat Politècnica de \\ Catalunya-BarcelonaTech, c/ Jordi Girona 1-3, Building D1, E-08034 Barcelona, Spain \\ ${ }^{\mathrm{b}}$ Department of Environmental Chemistry, IDAEA-CSIC, c/Jordi Girona, 18-26, E-08034 Barcelona, Spain
}

\section{A R T I C LE INFO}

Article history:

Received 9 November 2018

Received in revised form 20 December 2018

Accepted 2 January 2019

Available online $\mathrm{xxx}$

Editor: Daniel CW Tsang

Keywords:

Algae

Anaerobic digestion

Bioenergy

Contaminants of emerging concern

Sewage sludge

\begin{abstract}
A B S T R A C T
Microalgal-based wastewater treatment plants are conceived as low cost and low energy consuming systems The operation of these plants involves the management of primary sludge and microalgal biomass. The aim of this study is to analyse the anaerobic co-digestion of both by-products in terms of biogas production and contaminants of emerging concern removal. The co-digestion of microalgae and primary sludge $(25 / 75 \%$ on a volatile solids basis) was investigated in continuous reactors and compared to microalgae mono-digestion at a hydraulic retention time of 20 days. Results showed how the co-digestion enhanced the anaerobic digestion of microalgal biomass, since primary sludge is a more readily biodegradable substrate, which increased the methane production by $65 \%$ and reduced the risk of ammonia toxicity. Regarding the contaminants, musk fragrances (galaxolide and tonalide) and triclosan showed the highest abundance on primary sludge $(0.5-25 \mu \mathrm{g}$ / g TS), whereas caffeine, methyl dihydrojasmonate and triphenyl phosphate were barely detected in both substrates $(<0.1 \mu \mathrm{g} / \mathrm{g} \mathrm{TS})$. The removal of these contaminants was compound-depending and ranged from no removal to up to $90 \%$. On the whole, microalgae mono-digestion resulted in a higher removal of selected contaminants than the co-digestion with primary sludge.
\end{abstract}

\section{Introduction}

Microalgal-based wastewater treatment systems, such as high rate algal ponds (HRAPs), are low cost technologies that remove organic matter and nutrients from wastewater thanks to the symbiosis between microalgae and bacteria. Indeed, microalgae release oxygen through photosynthesis, which is used by heterotrophic bacteria for organic matter biodegradation. Thus, there is no need for external aeration, reducing the energy consumption associated with conventional wastewater treatment systems as activated sludge. Moreover, microalgae biomass can be harvested and digested or co-digested with other substrates, such as primary sludge from primary treatment settlers or grease trap waste, in order to produce bioenergy (Iyovo et al., 2010).

The co-digestion of primary sludge and microalgae in the same reactor may enhance the anaerobic digestion performance while easing the management of both by-products (Mata-Alvarez et al., 2014). This strategy could improve microalgae anaerobic digestion rate and extent by increasing the carbon to nitrogen ratio $(\mathrm{C} / \mathrm{N})$ and reducing the risk of ammonia toxicity, due to the high content of proteins in microalgae cells (Magdalena et al., 2018). In addition, co-digestion may promote macro and micro-nutrient equilibrium, balance the moisture content, optimize the organic loading rate and dilute possible inhibitory compounds released during the anaerobic digestion

\footnotetext{
* Corresponding author.

Email address: ivet.ferrer@upc.edu (I. Ferrer)
}

process (Astals et al., 2015; Herrmann et al., 2016; Schwede et al., 2013a). Indeed, the co-digestion of the cyanobacteria Spirulina maxima $(50 \%)$ and sewage sludge $(50 \%)$ in continuous reactors at a hydraulic retention time (HRT) of 20 days increased by 2.1 -fold the methane yield as compared to the cyanobacteria mono-digestion. The authors also observed a synergy when mixing both substrates attributed to the $\mathrm{C} / \mathrm{N}$ ratio increase (Samson and LeDuy, 1983). So far, most research has been conducted co-digesting microalgae with waste activated sludge (WAS) or sewage sludge (Caporgno et al., 2015; Olsson et al., 2014; Thorin et al., 2017), while only a few studies tested microalgae co-digestion with primary sludge in batch test (Hlavínek et al., 2016; Mahdy et al., 2015). A 15\% increase in the methane yield was reported after primary sludge co-digestion in biochemical methane potential (BMP) tests (Mahdy et al., 2015). To the best of our knowledge, the co-digestion of microalgal biomass grown in wastewater and primary sludge in continuous reactors has only been explored in a previous study, that investigated thermally pretreated microalgae and primary sludge co-digestion (Solé-Bundó et al., 2018). Even if the energy balance was estimated to be positive, the study of the process without applying any pretreatment was pointed out to further increase the energy gain. Consequently, this study addressed the co-digestion of untreated microalgae and primary sludge in continuous reactors.

In addition to biogas, the anaerobic digestion process gives place to a stabilized digestate, which can be applied as biofertilizer in agriculture (Solé-Bundó et al., 2017a). In this context, the occurrence of contaminants of emerging concern, such as pharmaceuticals and per- 


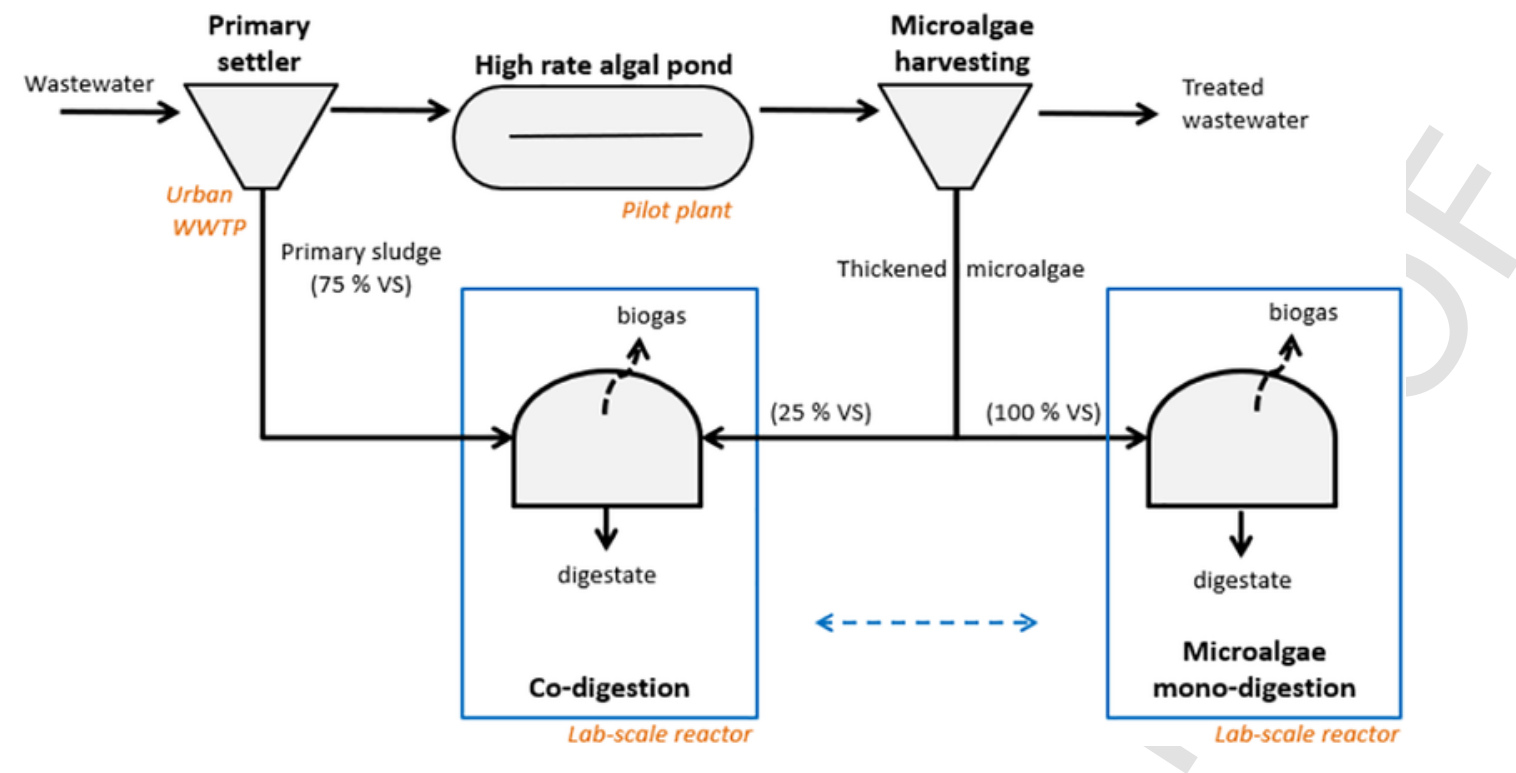

Fig. 1. Experimental set up.

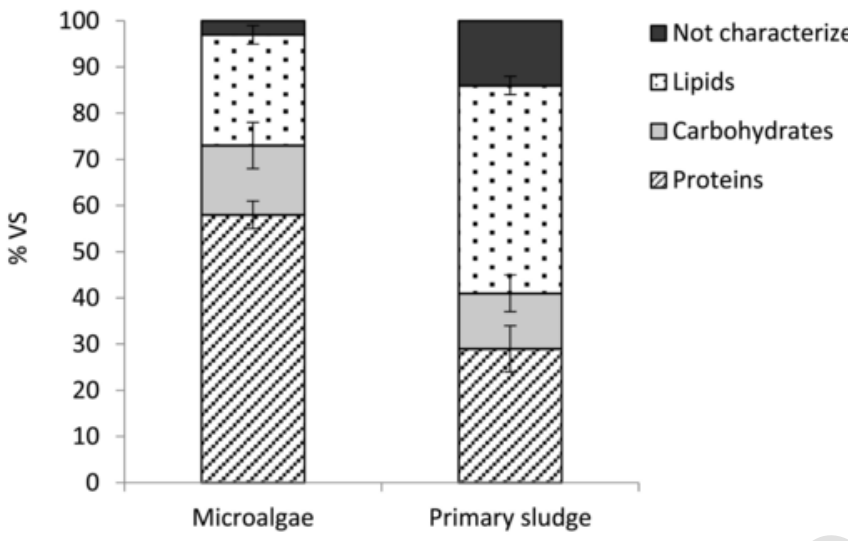

Fig. 2. Microalgae and primary sludge macromolecular composition $(n=3)$.

sonal care products (PPCPs), in sewage sludge is an important issue to be addressed (Matamoros et al., 2012). It is known that conventional wastewater treatment systems (e.g. activated sludge systems) are generally not designed to treat these contaminants and that sludge contains considerably high amounts of hydrophobic compounds such as musk fragrances or triclosan $(\log K o w>4)$ (Clarke and Smith, 2011). Hence, sludge reuse in agriculture is a potential source of crop exposure to these compounds (Macherius et al., 2012). In this regard, different approaches have been used to remove these contaminants from sewage sludge, such as anaerobic digestion or sludge treatment reed bed (STRB) systems. For instance, Carballa et al. (2007) found that musk fragrances were removed by $60-70 \%$ after anaerobic digestion, but other authors showed no removal under similar conditions (Clara et al., 2010). On the other hand, Chen et al. (2009) observed that these compounds are barely removed in STRBs after one year, and suggested to increase the treatment time from two to more than three years. Nevertheless, studies addressing the presence and removal of contaminants of emerging concern in anaerobic reactors degrading microalgal biomass are still missing.

The aim of this study is to evaluate the co-digestion of microalgal biomass and primary sludge, both of them by-products of a pilot-scale microalgae-based WWTP. For this, the co-digestion of microal-
Table 1

Biogas production from microalgal biomass anaerobic digestion and co-digestion with primary sludge. Mean values* \pm standard deviation.

\begin{tabular}{|c|c|c|}
\hline Parameter & $\begin{array}{l}\text { Microalgae mono- } \\
\text { digestion }\end{array}$ & $\begin{array}{l}\text { Co- } \\
\text { digestion }\end{array}$ \\
\hline \multicolumn{3}{|l|}{ Operational conditions } \\
\hline HRT (days) & 20 & 20 \\
\hline OLR ( $\mathrm{kg} \mathrm{VS} / \mathrm{m}^{3} \cdot$ day $)$ & $1.91 \pm 0.27$ & $1.89 \pm 0.26$ \\
\hline \multicolumn{3}{|l|}{ Biogas production } \\
\hline $\begin{array}{l}\text { Methane production rate } \\
\left(\mathrm{m}^{3} \mathrm{CH}_{4} / \mathrm{L} \cdot \text { day }\right)\end{array}$ & $0.38 \pm 0.10$ & $0.63 \pm 0.13^{\mathrm{a}}$ \\
\hline Methane yield $\left(\mathrm{m}^{3} \mathrm{CH}_{4} / \mathrm{kg} \mathrm{VS}\right)$ & $0.20 \pm 0.04$ & $0.33 \pm 0.05^{\mathrm{a}}$ \\
\hline Methane content in biogas $\left(\% \mathrm{CH}_{4}\right)$ & $65.5 \pm 1.4$ & $66.5 \pm 1.5$ \\
\hline \multicolumn{3}{|l|}{ Removal efficiency } \\
\hline TS removal (\%) & $19.3 \pm 4.4$ & $38.9 \pm 1.6^{\mathrm{a}}$ \\
\hline VS removal $(\%)$ & $25.1 \pm 4.1$ & $46.8 \pm 1.6^{\mathrm{a}}$ \\
\hline COD removal (\%) & $30.8 \pm 8.8$ & $53.2 \pm 13.6^{\mathrm{a}}$ \\
\hline \multicolumn{3}{|l|}{ Influent } \\
\hline $\mathrm{pH}$ & $6.8 \pm 0.3$ & $6.0 \pm 0.4^{\mathrm{a}}$ \\
\hline TS $[\%(w / w)]$ & $5.4 \pm 0.3$ & $5.2 \pm 0.3$ \\
\hline VS $[\%(w / w)]$ & $4.0 \pm 0.1$ & $3.9 \pm 0.3$ \\
\hline $\mathrm{VS} / \mathrm{TS}(\%)$ & $73.8 \pm 4.0$ & $75.8 \pm 3.2$ \\
\hline $\operatorname{COD}(\mathrm{g} / \mathrm{L})$ & $67.7 \pm 12.3$ & $72.6 \pm 12.6$ \\
\hline TKN (g/L) & $4.4 \pm 0.4$ & $2.8 \pm 0.3^{\mathrm{a}}$ \\
\hline $\mathrm{N}-\mathrm{NH}_{4}(\mathrm{mg} / \mathrm{L})$ & $80 \pm 40$ & $88 \pm 32$ \\
\hline VFA (mg HAc/L) & $1026 \pm 404$ & $2962 \pm 569^{\mathrm{a}}$ \\
\hline \multicolumn{3}{|l|}{ Effluent } \\
\hline $\mathrm{pH}$ & $7.5 \pm 0.3$ & $7.4 \pm 0.3$ \\
\hline TS $[\%(w / w)]$ & $4.5 \pm 0.2$ & $3.2 \pm 0.1^{\mathrm{a}}$ \\
\hline $\operatorname{VS}[\%(w / w)]$ & $2.9 \pm 0.2$ & $2.1 \pm 0.1^{\mathrm{a}}$ \\
\hline VS/TS (\%) & $64.9 \pm 2.7$ & $65.6 \pm 3.2$ \\
\hline $\operatorname{COD}(\mathrm{g} / \mathrm{L})$ & $47.4 \pm 8.3$ & $32.9 \pm 7.8^{\mathrm{a}}$ \\
\hline TKN (g/L) & $4.4 \pm 0.2$ & $2.6 \pm 0.0^{\mathrm{a}}$ \\
\hline $\mathrm{N}-\mathrm{NH}_{4}(\mathrm{~g} / \mathrm{L})$ & $1.3 \pm 0.2$ & $0.74 \pm 0.1^{\mathrm{a}}$ \\
\hline VFA (mgHAc/L) & $269 \pm 174$ & $156 \pm 137^{\mathrm{a}}$ \\
\hline $\operatorname{CST}(\mathrm{s})$ & $1575 \pm 75$ & $274 \pm 56^{\mathrm{a}}$ \\
\hline $\operatorname{CST}(\mathrm{s} / \mathrm{g}$ TS $)$ & $35 \pm 2$ & $8 \pm 2^{a}$ \\
\hline
\end{tabular}

${ }^{\text {a }}$ Stand for significantly higher values between paired columns $(\rho=0.05)$.

* The periodicity and extent of each parameter measurement is detailed in the Material and methods section.

gae and primary sludge (25/75\% on a volatile solids (VS) basis) was investigated in continuous reactors and compared to the anaerobic digestion of microalgae alone. Furthermore, an energy assessment was carried out to determine the potential scalability of this technology. 
Table 2

Energy assessment of microalgal biomass anaerobic digestion and co-digestion with primary sludge.

\begin{tabular}{lll}
\hline Parameter & Control microalgae & Co-digestion \\
\hline $\mathrm{E}_{\mathrm{i}}(\mathrm{GJ} /$ day $)$ & 0.90 & 0.90 \\
$\mathrm{E}_{\mathrm{i}, \text { heat }}(\mathrm{GJ} /$ day $)$ & 0.82 & 0.82 \\
$\mathrm{E}_{\mathrm{i}, \text { electricity }}(\mathrm{GJ} /$ day $)$ & 0.08 & 0.08 \\
$\mathrm{E}_{\mathrm{o}}(\mathrm{GJ} /$ day $)$ & 2.45 & 4.06 \\
$\Delta \mathrm{E}=\mathrm{E}_{0}-\mathrm{E}_{\mathrm{i}}(\mathrm{GJ} /$ day $)$ & 1.55 & 3.16 \\
$\mathrm{E}_{\mathrm{o}} / \mathrm{E}_{\mathrm{i}}$ & 2.7 & 4.5 \\
\hline
\end{tabular}

Finally, the most common contaminants of emerging concern were analysed before and after the anaerobic digestion process in order to study their presence and fate.

\section{Material and methods}

\subsection{Substrates and inoculum}

The experimental set-up was located at the laboratory of the GEMMA research group (Universitat Politècnica de Catalunya-BarcelonaTech, Spain). Microalgal biomass, hereafter called microalgae, was harvested from a pilot $\operatorname{HRAP}\left(0.5 \mathrm{~m}^{3} ; 1.5 \mathrm{~m}^{2}\right)$ treating wastewater from the municipal sewer of Barcelona. The HRAP received the primary effluent of a settling tank $(7 \mathrm{~L} ; 0.9 \mathrm{~h}$ of
HRT) and was used as secondary treatment unit. Microalgae were harvested from a secondary settler $(9 \mathrm{~L} ; 9 \mathrm{~h}$ of HRT) and thickened by gravity in laboratory Imhoff cones at $4{ }^{\circ} \mathrm{C}$ for $24 \mathrm{~h}$. A detailed description of the wastewater treatment system operation and performance may be found elsewhere (Passos et al., 2015). Microalgae species were periodically identified over the continuous reactors operation using specific literature (Palmer, 1962). The optical microscope (Motic BA310E, China) used was equipped with a camera MRc5, using the software Axioplan LE.

Primary sludge and digested sludge used as inoculum for digesters start-up came from a municipal WWTP located nearby. Thickened primary sludge was periodically collected (every 3 weeks) and stored at $4{ }^{\circ} \mathrm{C}$ before use. The inoculum was taken from a mesophilic digester.

\subsection{Digesters operation}

The anaerobic co-digestion of microalgae with primary sludge was evaluated in two lab-scale reactors $(2 \mathrm{~L})$, with a useful volume of $1.5 \mathrm{~L}$. The co-digestion of microalgal biomass and primary sludge (25/75\% on a VS basis) and the anaerobic mono-digestion of microalgal biomass (control) were simultaneously investigated. The proportion of microalgae and sludge was selected according to the results of a previous BMP test, where different proportions of microalgae and primary sludge were compared (Solé-Bundó et al., 2018). Reactors were operated under mesophilic conditions $\left(37 \pm 1^{\circ} \mathrm{C}\right)$ by

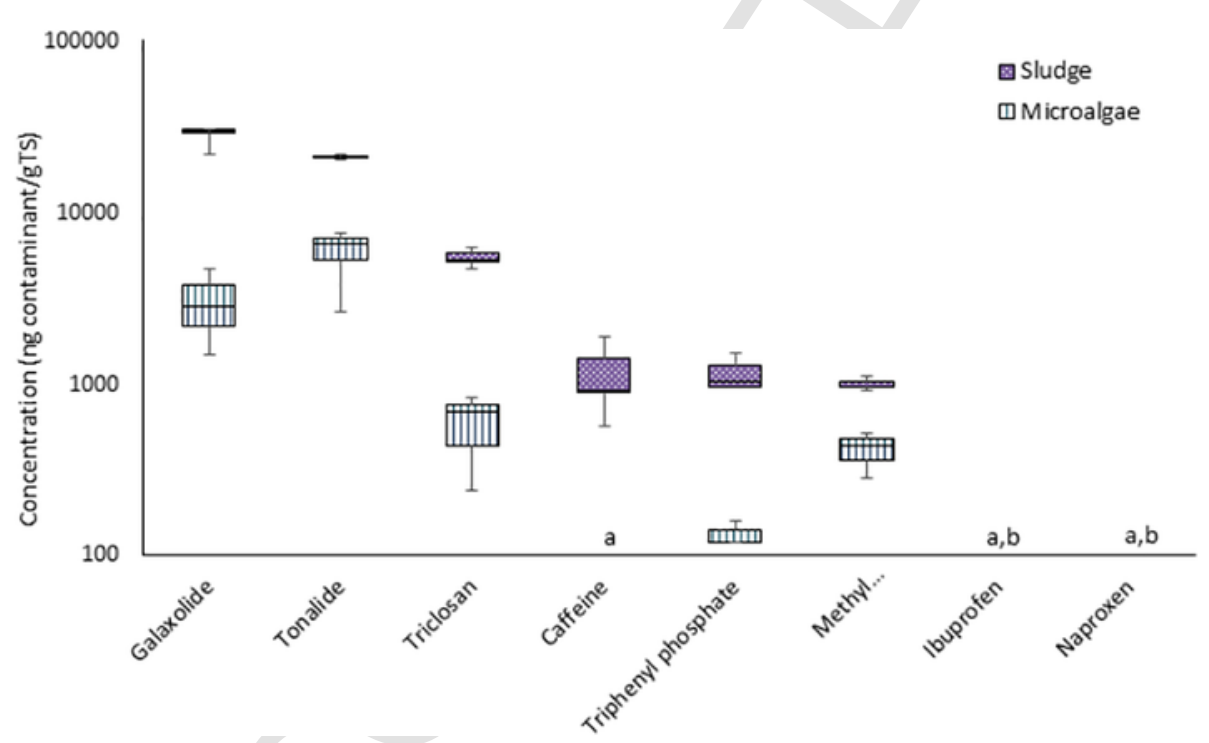

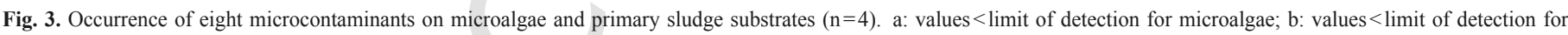
sludge.

Table 3

Concentration of microcontaminants of the influents and effluents and microcontaminants removal in anaerobic digesters $(n=6)$.

\begin{tabular}{|c|c|c|c|c|c|c|}
\hline \multirow[t]{2}{*}{ Microcontaminant } & \multicolumn{3}{|c|}{ Microalgae mono-digestion } & \multicolumn{3}{|l|}{ Co-digestion } \\
\hline & Influent (ng/g TS) & Effluent (ng/g TS) & Removal (\%) & Influent (ng/g TS) & Effluent (ng/g TS) & Removal (\%) \\
\hline Galaxolide & $2791 \pm 1002$ & $2273 \pm 675$ & 32 & $18,836 \pm 3122$ & $33,190 \pm 7955$ & -10 \\
\hline Tonalide & $5748 \pm 1941$ & $4057 \pm 1236$ & 41 & $11,271 \pm 617$ & $17,376 \pm 3885$ & 3.7 \\
\hline Triclosan & $576 \pm 232$ & $417 \pm 180$ & 39 & $3580 \pm 406$ & $5940 \pm 1757$ & -3.7 \\
\hline Methyl dihydrojasmonate & $37 \pm 13$ & $26 \pm 9$ & 41 & $47 \pm 6$ & $22 \pm 5$ & 71 \\
\hline Caffeine & $<\mathrm{LOD}$ & $<\mathrm{LOD}$ & - & $81 \pm 29$ & $<\mathrm{LOD}$ & $>92$ \\
\hline Triphenyl phosphate & $14 \pm 4$ & $<$ LOD & - & $75 \pm 18$ & $43 \pm 23$ & 64 \\
\hline
\end{tabular}

Note: $\mathrm{LOD}=$ limit of detection. 
implementing an electric heating cover (Selecta, Spain). Constant mixing was provided by a magnetic stirrer (Thermo Scientific). Reactors were operated at a HRT of 20 days and were considered to be under steady-state after three HRTs. Afterwards, anaerobic digestion performance was further monitored during 2 complete HRTs ( $\sim 6$ weeks). The total experimental period of the digesters was 100 days.

The reactors were operated on a daily feeding basis. The same volume was purged from and added to digesters using plastic syringes $(75 \mathrm{~mL})$. Biogas production was measured by water displacement and the methane content was periodically analysed by gas chromatography (GC) as described by Solé-Bundó et al. (2017b). To keep the same OLR in both digesters, the reactors feedstock was prepared once a week with a VS content of $4 \%$. To adjust the solids concentration, distilled water was used when necessary. A schematise of the experimental set up is shown in Fig. 1.

\subsection{Energy balance calculations}

The theoretical energy balance of full-scale reactors was estimated from experimental data, considering a flow rate of $10 \mathrm{~m}^{3} /$ day and a useful volume of $200 \mathrm{~m}^{3}$ for a HRT of 20 days. Electricity and heat requirements for microalgal biomass pretreatment and anaerobic digestion were calculated according to Passos and Ferrer (2014).

Input heat was calculated as the energy required to heat influent biomass from ambient temperature $(\mathrm{Ta})$ to digestion temperature $(\mathrm{Td})$, according to Eq. (1). The density $(\rho)$ and specific heat $(\gamma)$ of microalgal biomass were assumed to be the same as water (i.e. $1000 \mathrm{~kg} / \mathrm{m}^{3}$ and $4.18 \mathrm{~kJ} / \mathrm{kg} \cdot{ }^{\circ} \mathrm{C}$, respectively). Heat losses through the reactor wall were calculated assuming the heat transfer coefficient $(\mathrm{k})$ equal to $1 \mathrm{~W} / \mathrm{m}^{2}$.day. The reactor wall surface area was calculated from the reactor useful volume, considering a 2:1 diameter to height ratio. The reactor bottom and top were not accounted for.

$$
\text { Ei, heat }=\rho \cdot \mathrm{Q} \cdot \gamma \cdot(\mathrm{Td}-\mathrm{Ta})+\mathrm{k} \cdot \mathrm{A} \cdot(\mathrm{Td}-\mathrm{Ta}) \cdot 86.4
$$

where Ei,heat: input heat $(\mathrm{kJ} /$ day $)$; $\rho$ : density $\left(\mathrm{kg} / \mathrm{m}^{3}\right)$; Q: flow rate $\left(\mathrm{m}^{3} /\right.$ day $) ; \gamma$ : specific heat $\left(\mathrm{kJ} / \mathrm{kg} \cdot{ }^{\circ} \mathrm{C}\right)$; Td: anaerobic digestion temperature $\left(37^{\circ} \mathrm{C}\right)$; Ta: ambient temperature $\left(20^{\circ} \mathrm{C}\right)$; $\mathrm{k}$ : heat transfer coefficient $\left(\mathrm{W} / \mathrm{m}^{2} \cdot{ }^{\circ} \mathrm{C}\right)$; A: surface area of the reactor wall $\left(\mathrm{m}^{2}\right)$.

Furthermore, input electricity for anaerobic digestion was estimated as the energy required for biomass pumping and reactor mixing, which were assumed to be $1800 \mathrm{~kJ} / \mathrm{m}^{3}$ and $300 \mathrm{~kJ} / \mathrm{m}^{3}$ reactor .day, respectively (Eq. (2)).

$$
\text { Ei, electricity }=Q \cdot \theta+V \cdot \omega
$$

where Ei,electricity: input electricity ( $\mathrm{kJ} /$ day); Q: flow rate $\left(\mathrm{m}^{3} /\right.$ day); $\theta$ : electricity consumption for pumping $\left(\mathrm{kJ} / \mathrm{m}^{3}\right) ; \mathrm{V}$ : useful volume $\left(\mathrm{m}^{3}\right)$; $\omega$ : electricity consumption for mixing $\left(\mathrm{kJ} / \mathrm{m}^{3}\right.$ reactor $\left.\mathrm{day}\right)$.

The energy output of the process was calculated from the methane production rate $\left(\mathrm{P},{ }_{\mathrm{CH}}\right)$ of each reactor (co-digestion and microalgae mono-digestion), according to Eq. (3). The lower heating value of methane $(\xi)$ was assumed to be $35,800 \mathrm{~kJ} / \mathrm{m}^{3} \mathrm{CH}_{4}$. An efficiency of $90 \%$ on energy conversion was considered $(\eta)$.

$$
\mathrm{Eo}=\mathrm{P},{ }_{\mathrm{CH} 4} \cdot \xi \cdot \mathrm{V} \cdot \eta
$$

where Eo: output energy $(\mathrm{kJ} / \mathrm{d}) ; \mathrm{P}_{\mathrm{CH} 4}$ : methane production rate $\left(\mathrm{m}^{3} \mathrm{CH}_{4} / \mathrm{m}^{3}\right.$ reactor day); $\xi$ : lower heating value of methane $\left(\mathrm{kJ} / \mathrm{m}^{3}\right.$ $\left.\mathrm{CH}_{4}\right)$; V: useful volume $\left(\mathrm{m}^{3}\right) ; \eta$ : energy conversion efficiency $(\%)$.

Finally, results were expressed as energy balance $(\Delta \mathrm{E})$ and energy ratio $(\mathrm{Eo} / \mathrm{Ei})$ for both reactors (co-digestion and microalgae mono-digestion). The energy balance was calculated as the difference between the energy output and energy input (heat and electricity) (Eq. (4)), while the energy ratio was calculated by dividing the energy output by the energy input (heat and electricity) (Eq. (5)).

$$
\begin{aligned}
& \Delta \mathrm{E}=\mathrm{E}_{\mathrm{o}}-\left(\mathrm{E}_{\mathrm{i} \text {,heat }}+\mathrm{E}_{\mathrm{i} \text {,electricity }}\right) \\
& \mathrm{E}_{\mathrm{o}} / \mathrm{E}_{\mathrm{i}}=\mathrm{E}_{\mathrm{o}} /\left(\mathrm{E}_{\mathrm{i} \text {,heat }}+\mathrm{E}_{\mathrm{i} \text {,electricity }}\right)
\end{aligned}
$$

\subsection{Analytical procedures}

Physical-chemical parameters of the influent and effluent of both reactors were determined as follows: temperature was monitored daily. The $\mathrm{pH}$ was neither controlled nor regulated, but measured twice a week with a Crison Portable $506 \mathrm{pH}$-meter. The concentration of TS, VS and total Kjeldhal nitrogen (TKN) were determined according to Standard Methods (APHA et al., 2005) and ammonium nitrogen $\left(\mathrm{N}-\mathrm{NH}_{4}\right)$ according to the Solorzano method (Solorzano, 1969) on a weekly basis. Volatile fatty acids (VFA) concentrations were measured once a week by injecting $1 \mu \mathrm{L}$ of centrifuged $(4200 \mathrm{rpm}$ for $8 \mathrm{~min})$ and filtered $(0.2 \mu \mathrm{m})$ samples into an Agilent $7820 \mathrm{~A} \mathrm{GC}$ after sulphuric acid and diisopropyl ether addition. The GC was equipped with an auto-sampler, flame ionization detector and a capillary column (DP-FFAB Agilent $30 \mathrm{~m} \times 0.25 \mathrm{~mm} \times 0.25 \mu \mathrm{m}$ ), and operated at injector and detector temperatures of 200 and $300^{\circ} \mathrm{C}$, respectively, with helium as carrier gas.

The biochemical composition of microalgae and primary sludge was analysed three times over the experiment. The carbohydrate content was determined by a phenol-sulphuric acid method after acid hydrolysis and measured by spectrophotometry (Spectronic Genesys 8). The protein content was determined from the TKN, using a TKN/protein conversion factor of 5.95 (González López et al., 2010). The lipid content was determined by the Soxhlet extraction method (APHA et al., 2005). Values were expressed as percentage of lipids, carbohydrates and proteins over the VS content.

The biogas composition was calculated by measuring the percentage of methane and carbon dioxide in the reactor headspace using a GC equipped with a thermal conductivity detector (TCD) (Trace GC Thermo Finnigan with Hayesep packed column). The injector/detector/oven temperatures were $150,250,35^{\circ} \mathrm{C}$, respectively. Helium gas was used as carrier.

The analytical procedures and quality parameters for the determination of microcontaminants (caffeine, methyl dihydrojasmonate, triphenyl phosphate, galaxolide, tonalide and triclosan, ibuprofen, naproxen) in microalgae and sludge samples are described elsewhere (Matamoros et al., 2015).

\subsection{Contaminants of emerging concern data analysis}

The concentrations of selected contaminants of emerging concern, hereafter called microcontaminants, were analysed for the feedstock (microalgae and primary sludge) and both digestates over a period of six weeks (weekly integrated samples).

The percentage of each microcontaminant removed in the anaerobic reactors was calculated according to the following mass balance (Eq. (6)): 


$$
\begin{aligned}
C_{\text {remov }}(\%) & =\frac{C_{\text {in }} \cdot T S_{\text {in }} \cdot Q_{\text {in }}-C_{\text {out }} \cdot T S_{\text {out }} \cdot Q_{\text {out }}}{C_{\text {in }} \cdot T S_{\text {in }} \cdot Q_{\text {in }}} \cdot 100 \\
& =\frac{C_{\text {in }} \cdot T S_{\text {in }}-C_{\text {out }} \cdot T S_{\text {out }}}{C_{\text {in }} \cdot T S_{\text {in }}} \cdot 100
\end{aligned}
$$

where $\mathrm{C}_{\text {remov }}$ is the removal of each microcontaminant in $\%, \mathrm{C}_{\text {in }}$ and $\mathrm{C}_{\text {out }}$ are the concentrations of the microcontaminant in the influent (feedstock) and effluent (digestate), respectively, expressed as ng microcontaminant/g TS; $\mathrm{TS}_{\text {in }}$ and $\mathrm{TS}_{\text {out }}$ are the total solids concentration of the influent and effluent, respectively, expressed as gTS/L, and $\mathrm{Q}_{\text {in }}=\mathrm{Q}_{\text {out }}$ is the flow rate, expressed in $\mathrm{L} /$ day.

\subsection{Statistics and data analysis}

The significant differences between both reactors were determined by the ANOVA test using R 3.0.1 software (The R Foundation for Statistical Computing). $\rho=0.05$ was set as the level of statistical significance.

\section{Results and discussion}

\subsection{Biogas production from microalgal biomass and primary sludge anaerobic co-digestion under continuous flow conditions}

\subsubsection{Substrates characterization}

Microscope examination showed that microalgae were mainly composed of Chlorella sp. Microalgae individuals formed flocs, which facilitated their settling and harvesting. An average concentration of 5.4\% TS was achieved after settling and thickening. Biochemical analysis indicated that microalgae were mainly composed of proteins $(58 \%)$, followed by lipids (24\%) and carbohydrates (15\%) (Fig. 2 ). These values are in accordance with those reported in the literature for Chlorella species (Safi et al., 2014).

In contrast, primary sludge had a higher amount of lipids (45\%), followed by proteins (29\%) and carbohydrates (12\%) (Fig. 2). Other studies reported a similar protein content, but with a higher content of carbohydrates than lipids (Jimenez et al., 2013; Mahdy et al., 2014). This was attributed to the high content of fibers in sludge. Indeed, primary sludge composition is highly variable and depends on several factors, such as wastewater source and characteristics, pretreatment and primary treatment steps design. Since the sludge investigated in this study presented a high lipids content, a high methane potential was expected (Sialve et al., 2009). However, possible inhibition due to long-chain fatty acids (LCFA) must be considered (Cirne et al., 2007). Apart from its composition, primary sludge also differs from microalgae in its structure. While Chlorella sp. has a complex structure characterized by resistant cell walls, primary sludge is formed by colloidal organic matter which can be easily converted into biogas.

\subsubsection{Reactors performance}

Continuous co-digestion of microalgae and primary sludge (25/ $75 \%$ on a VS basis) and microalgae mono-digestion (control) in lab-scale reactors at a HRT of 20 days was monitored over 100 days. In the case of co-digestion, the methane production increased by $65 \%$ as compared to microalgae mono-digestion: the average methane yield increased from 0.20 to $0.33 \mathrm{~m}^{3} \mathrm{CH}_{4} / \mathrm{kg}$ VS and the methane production rate from 0.38 to $0.63 \mathrm{~m}^{3} \mathrm{CH}_{4} / \mathrm{m}^{3}$.day (Table 1). Consistently, the VS and COD removal in the microalgae digester was 25 and $31 \%$, respectively, while the co-digestion digester achieved removal efficiencies of 47 and $53 \%$, respectively. Thus, the co-digestion with primary sludge enhanced the anaerobic digestion of microalgae, leading to higher substrate biodegradability and biogas production. This is mainly because primary sludge is a more readily biodegradable carbon rich substrate. In addition, synergistic effects due to substrates co-digestion could have contributed to enhance their biodegradability, as already reported by other authors. For instance, Olsson et al. (2014) observed a $23 \%$ increase in methane yield when co-digesting sewage sludge with microalgae slurry $(63 / 37 \%)$ in BMP tests compared to sewage sludge mono-digestion. Also, a kinetics improvement by $116 \%$ was observed when lipid-spend microalgae residue was co-digested with waste activated sludge (Neumann et al., 2015). Furthermore, higher methane yields were achieved when co-digesting microalgae with primary sludge in batch experiments $(5-10 \%)$ in comparison with the theoretically calculated methane yield of each substrate (Mahdy et al., 2015).

In the present study the average methane yield of microalgae was high $\left(0.20 \mathrm{~m}^{3} \mathrm{CH}_{4} / \mathrm{kg} \mathrm{VS}\right)$ compared to previous studies. This might be attributed to the predominant microalgae species. Indeed, it has been proven that microalgae biodegradability is highly species-dependent (Mussgnug et al., 2010; Passos et al., 2015). For instance, Chlorella is more easily biodegraded than other species grown spontaneously in wastewater treatment systems which are typically characterized by their resistant cell walls. Indeed, a previous study on the anaerobic digestion of a mixed culture of Chlorella sp., Monoraphidium sp. and diatoms grown in the same HRAP as in the present study, showed a much lower average methane yield $\left(0.12 \mathrm{~m}^{3} \mathrm{CH}_{4} / \mathrm{kg}\right.$ VS vs. $0.20 \mathrm{~m}^{3} \mathrm{CH}_{4} / \mathrm{kg}$ VS, respectively) (Solé-Bundó et al., 2017b). Even when applying a thermal pretreatment before microalgae anaerobic digestion, the methane yield achieved was lower than that obtained in this study (Passos and Ferrer, 2015, 2014). Indeed, the methane yield was $0.17 \mathrm{~m}^{3} \mathrm{CH}_{4} / \mathrm{kg}$ VS for Oocystis sp. (Passos and Ferrer, 2015) and $0.18 \mathrm{~m}^{3} \mathrm{CH}_{4} / \mathrm{kg}$ VS for a mixed culture composed by Monoraphidium sp. and Stigeoclonium sp. (Passos and Ferrer, 2014). In this sense, the predominance of Chlorella species in wastewater treatment HRAP helps increasing the bioenergy production from harvested microalgae biomass.

The present study was characterized by a high OLR $(1.9 \mathrm{~kg}$ VS/ $\mathrm{m}^{3}$.day) in the anaerobic digesters, resulting from the high concentration of TS in harvested biomass. Even if high OLR can lead to high methane production rate, they also increase the $\mathrm{N}-\mathrm{NH}_{4}$ concentration inside digesters, eventually causing inhibition. In this study, the $\mathrm{N}_{-} \mathrm{NH}_{4}$ concentration in the digestate was 1.3 and $0.7 \mathrm{~g} \mathrm{~N}-\mathrm{NH}_{4} / \mathrm{L}$ for microalgae mono-digestion and co-digestion, respectively (Table 1). Some authors have reported ammonium toxic concentrations of $1.7 \mathrm{~g} / \mathrm{L}$ (Schwede et al., 2013b) or even $1.5 \mathrm{~g} / \mathrm{L}$ when working at high $\mathrm{pH}$ (Rajagopal et al., 2013). In this study, the $\mathrm{N}_{-} \mathrm{NH}_{4}$ concentration in the microalgae digester was close to these values, being 2 times higher than in the microalgae and primary sludge co-digester. However, the performance of both digesters was stable during the whole experimental period, with an average $\mathrm{pH}$ of 7.4-7.5 for microalgae digestion and co-digestion, respectively (Table 1). Also, VFA average concentration in the digestates was $269 \mathrm{mg} 156 \mathrm{mg} \mathrm{HAc} / \mathrm{L}$ in the microalgae mono- and co-digestion, respectively. These values were much lower than the proposed threshold for a proper anaerobic digestion performance (e.g. 1.5 g HAc/L) (Boe et al., 2010). Even if ammonia inhibition was not detected in this study, co-digestion of microalgae with primary sludge seems a good strategy to enhance reactors stability by reducing the ammonium concentration that may eventually lead to ammonia inhibition. For instance, the enzymatic pretreatment of Chlorella vulgaris with a protease enhanced the release of am-

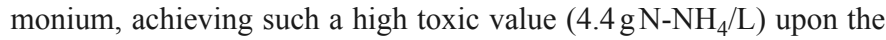


anaerobic digestion with an OLR of $2.1 \mathrm{~g} \mathrm{VS} / \mathrm{L}$-day (Mahdy et al., 2017).

Regarding the digestate dewaterability, the CST values were consistently lower in the case of microalgae and primary sludge co-digestion as compared to microalgae mono-digestion $(1575$ s vs. 274 s, respectively), showing how the co-digestion with primary sludge significantly improved the microalgae digestate dewaterability. This is mainly because primary sludge presents a higher dewaterability than microalgae.

\subsubsection{Energy assessment}

The energy assessment of microalgae anaerobic digestion with and without co-digestion with primary sludge (Table 2) was based on the experimental results obtained in the continuous reactors (Table 1). Since energy balances $(\Delta \mathrm{E})$ were calculated by subtracting the energy input (heat and electricity) to the energy output from biogas production, positive values indicate energy surplus. As can be seen in Table 2, energy gain was observed in both cases, achieving a net energy production of 1.6 and $3.2 \mathrm{GJ} /$ day for the mono- and co-digestion reactor, respectively. Also, the $\mathrm{E}_{\mathrm{o}} / \mathrm{E}_{\mathrm{i}}$ ratio indicated that microalgae anaerobic digestion generated 2.7-fold the energy consumed. In the case of co-digestion, this ratio increased up to 4.5 -fold. Considering the transformation of this potential energy to electricity by means of cogeneration with an electricity conversion efficiency of $35 \%, 151$ and $307 \mathrm{kWh} /$ day could be provided by the mono- and co-digestion process, respectively. Passos et al. (2017) estimated in $140 \mathrm{kWh} /$ day the electricity demand of a HRAP with a similar biomass flow rate $\left(15-55 \mathrm{~m}^{3} /\right.$ day). Therefore, both configurations could supply the energy demand of the whole microalgae-based wastewater treatment system. However, with co-digestion there could even be an energy surplus to be sold back to the grid.

In view of these results, it can be concluded that anaerobic digestion is a key technology for bioenergy recovery in microalgal-based WWTPs, especially if microalgae are co-digested with primary sludge. In this regard, it is worthy to note that the amount of microalgae produced in these systems depends on the climate and shows a strong seasonality. A previous study which considered the same pilot-scale HRAP, showed that microalgae production over a year may vary from $3 \mathrm{~g}$ of suspended solids $(\mathrm{SS}) / \mathrm{m}^{3}$ in winter (minimum value) to $23 \mathrm{~g} \mathrm{SS} / \mathrm{m}^{3}$ in summer (maximum value) (Passos et al., 2015). On the other hand, the amount of primary sludge produced depends only on the characteristics of the influent wastewater and could be defined as constant over the year. Therefore, the proportion of microalgae and primary sludge produced in these systems may vary from $70 \%$ to $30 \%$ VS of microalgae depending on the season (Passos et al., 2017). Thus, the results of the energy balance obtained in this study should be taken as approximate values.

\subsection{Microcontaminants fate and removal}

\subsubsection{Occurrence}

The microcontaminants analysed in this study were selected based on their high concentration levels found in raw wastewater and sludge samples (Yang et al., 2016). Among the 8 analysed microcontaminants, only 6 were detected in the microalgae or primary sludge samples (Fig. 3). The concentration of compounds in sludge samples ranged from non-detectable to $25,000 \mathrm{ng} / \mathrm{g}$ TS. Galaxolide, tonalide and triclosan were the most abundant $(>500 \mathrm{ng} / \mathrm{g}$ TS) in agreement with the fact that they are the most hydrophobic ones $(\log$ Kow $>4)$. The concentration of these musk fragrances in sludge samples was similar to those found in the sludge from conventional WWTPs (Bester, 2004; Gonzalez-Gil et al., 2016; Kupper et al., 2004). Other compounds such as caffeine, triphenyl phosphate and methyl dihy- drojasmonate were also found, but at much lower concentration $(<100 \mathrm{ng} / \mathrm{g}$ TS). These compounds are usually detected at high concentrations in raw wastewater (Tran et al., 2018), but since they are hydrophilic their interaction with organic matter is low. For instance, caffeine has been detected in raw wastewater up to $300 \mu \mathrm{g} / \mathrm{L}$ (Buerge et al., 2003).

The concentration of microcontaminants was lower in the microalgae than in the primary sludge samples. This was due to the fact that primary sludge is separated in the primary treatment unit, where the concentration of these compounds is higher, whereas microalgae are separated in the secondary treatment unit, where the concentration of these compounds is lower. In this regard, it is important to notice that since the most abundant compounds are hydrophobic they tend to adsorb onto the organic matter and suspended solids, which are predominantly retained during the primary treatment. This was in accordance with previous studies that observed low concentration of these compounds in microalgae biomass from a HRAP in comparison with sludge from a conventional WWTP (Matamoros et al., 2015).

\subsubsection{Removal of microcontaminants during anaerobic digestion and co-digestion}

Table 3 shows the removal efficiency of selected microcontaminants during the mono-digestion of microalgae and co-digestion with sewage sludge. The removal for the compounds identified in all samples (i.e. galaxolide, tonalide, triclosan, and methyl dihydrojasmonate) ranged from no removal to $90 \%$. The compounds which occurred at the highest concentration showed the lowest removal efficiency due to their recalcitrance to biodegradation (Gonzalez-Gil et al., 2016). Indeed, a concentration phenomenon of these contaminants is observed in the effluents of the co-digestion samples. This is mainly because the degradation of these contaminants occurred slower than the degradation of organic matter in the reactors. A similar trend was observed by Matamoros et al. (2012). On the contrary, methyl dihydrojasmonate and caffeine showed higher removal efficiencies than musk fragrances and triclosan, which is in agreement with the high biodegradability for these compounds already observed in WWTPs (Schaider et al., 2017). Kupper et al. (2006), who carried out mass balances in a Swiss sludge monitoring network, reported that galaxolide and tonalide were reduced by $50 \%$ during sludge anaerobic digestion. Carballa et al. (2006) observed average removal of these compounds during the mesophilic and thermophilic anaerobic digestion, ranging between $60 \%$ and $70 \%$ (Table 3). On the contrary, Clara et al. (2011) reported no or only slight removal during sludge anaerobic digestion. The low efficiencies of the anaerobic digestion on the musk fragrances removal observed in this study are also in agreement with previous studies which observed that anaerobic digestion resulted in a lower removal of musk fragrances than aerobic digestion (Guerra et al., 2015).

The average removal of microcontaminants was of $38 \%$ and $15 \%$ for microalgae mono-digestion and co-digestion with primary sludge, respectively. The higher microcontaminants removal in microalgae mono-digestion might be due to the better biodegradation of microcontaminants due to microalgae chemical composition. This may suggest that bacteria grown under such condition will be more effective for removing microcontaminants, but other conclusions cannot be disregarded.

\section{Conclusions}

This study analysed the anaerobic co-digestion of microalgae and primary sludge, which represent the main by-products of microalgal-based wastewater treatment systems. The mesophilic co-digestion of microalgae and primary sludge $(25 / 75 \%$ on a VS basis) was investi- 
gated in continuous reactors and compared to microalgae mono-digestion at a hydraulic retention time of 20 days. Results showed how the co-digestion enhanced the anaerobic digestion of microalgal biomass, since primary sludge is a more readily biodegradable carbon rich substrate, leading to higher methane production ( $65 \%$ increase), while reducing the risk of ammonia toxicity. Moreover, the occurrence and fate of the most common contaminants of emerging concern was also evaluated. Musk fragrances (galaxolide and tonalide) and triclosan showed the highest abundance $(0.5-25 \mu \mathrm{g} / \mathrm{g}$ TS $)$. On the other hand, caffeine, methyl dihydrojasmonate and triphenyl phosphate were barely detected $(<0.1 \mu \mathrm{g} / \mathrm{g}$ dry weight $)$. The removal of these microcontaminants was compound-depending and ranged from no removal to $90 \%$. On the whole, microalgae mono-digestion resulted in a higher removal of selected microcontaminants than the co-digestion with primary sludge.

\section{Acknowledgements}

This research was funded by the Spanish Ministry of Science and Innovation (DIPROBIO project, CTM2012-37860) and the Spanish Ministry of Economy and Competitiveness (FOTOBIOGAS project, CTQ2014-57293-C3-3-R). Maria Solé is grateful to the Universitat Politècnica de Catalunya-BarcelonaTech for her $\mathrm{PhD}$ scholarship. Marianna Garfí is grateful to the Spanish Ministry of Economy and Competitiveness (Plan Estatal de Investigación Científica y Técnica y de Innovación 2013-2016, Subprograma Ramón y Cajal (RYC) 2016, RYC-2016-20059-).

\section{References}

A.P.H. Association, Eaton, A.D., A.W.W. Association, W.E. Federation, 2005. Standard Methods for the Examination of Water and Wastewater. APHA-AWWA-WEF, Washington, D.C.

Astals, S., Musenze, R.S., Bai, X., Tannock, S., Tait, S., Pratt, S., Jensen, P.D., 2015. Anaerobic co-digestion of pig manure and algae: impact of intracellular algal products recovery on co-digestion performance. Bioresour. Technol. 181, 97-104. https://doi.org/10.1016/j.biortech.2015.01.039.

Bester, K., 2004. Retention characteristics and balance assessment for two polycyclic musk fragrances (HHCB and AHTN) in a typical German sewage treatment plant. Chemosphere 57, 863-870. https://doi.org/10.1016/j.chemosphere.2004.08.032.

Boe, K., Batstone, D.J., Steyer, J.-P., Angelidaki, I., 2010. State indicators for monitoring the anaerobic digestion process. Water Res. 44, 5973-5980. https://doi.org/10. 1016/j.watres.2010.07.043.

Buerge, I.J., Poiger, T., Müller, M.D., Buser, H.-R., 2003. Caffeine, an anthropogenic marker for wastewater contamination of surface waters. Environ. Sci. Technol. 37 691-700. https://doi.org/10.1021/es020125z.

Caporgno, M.P., Trobajo, R., Caiola, N., Ibáñez, C., Fabregat, A., Bengoa, C., 2015. Biogas production from sewage sludge and microalgae co-digestion under mesophilic and thermophilic conditions. Renew. Energy 75, 374-380. https://doi. org/10.1016/j.renene.2014.10.019.

Carballa, M., Omil, F., Alder, A.C., Lema, J.M., 2006. Comparison between the conventional anaerobic digestion of sewage sludge and its combination with a chemical or thermal pre-treatment concerning the removal of pharmaceuticals and personal care products. Water Sci. Technol. 53, 109-117.

Carballa, M., Omil, F., Ternes, T., Lema, J.M., 2007. Fate of pharmaceutical and personal care products (PPCPs) during anaerobic digestion of sewage sludge. Water Res. 41, 2139-2150. https://doi.org/10.1016/j.watres.2007.02.012.

Chen, X., Pauly, U., Rehfus, S., Bester, K., 2009. Removal of personal care compounds from sewage sludge in reed bed container (lysimeter) studies - effects of macrophytes. Sci. Total Environ. 407, 5743-5749. https://doi.org/10.1016/j. scitotenv.2009.07.023

Cirne, D.G., Paloumet, X., Björnsson, L., Alves, M.M., Mattiasson, B., 2007. Anaerobic digestion of lipid-rich waste-effects of lipid concentration. Renew. Energy 32, 965-975. https://doi.org/10.1016/j.renene.2006.04.003.

Clara, M., Windhofer, G., Hartl, W., Braun, K., Simon, M., Gans, O., Scheffknecht, C., Chovanec, A., 2010. Occurrence of phthalates in surface runoff, untreated and treated wastewater and fate during wastewater treatment. Chemosphere 78, 1078-1084. https://doi.org/10.1016/j.chemosphere.2009.12.052.

Clara, M., Gans, O., Windhofer, G., Krenn, U., Hartl, W., Braun, K., Scharf, S., Scheffknecht, C., 2011. Occurrence of polycyclic musks in wastewater and receiving water bodies and fate during wastewater treatment. Chemosphere 82, 1116-1123. https://doi.org/10.1016/j.chemosphere.2010.11.041.

Clarke, B.O., Smith, S.R., 2011. Review of 'emerging' organic contaminants in biosolids and assessment of international research priorities for the agricultural use of biosolids. Environ. Int. 37, 226-247. https://doi.org/10.1016/j.envint.2010.06. 004

González López, C.V., García, M. del C.C., Fernández, F.G.A., Bustos, C.S., Chisti, Y., Sevilla, J.M.F., 2010. Protein measurements of microalgal and cyanobacteria biomass. Bioresour. Technol. 101, 7587-7591. https://doi.org/10.1016/j.biortech. 2010.04.077.

Gonzalez-Gil, L., Papa, M., Feretti, D., Ceretti, E., Mazzoleni, G., Steimberg, N., Pedrazzani, R., Bertanza, G., Lema, J.M., Carballa, M., 2016. Is anaerobic digestion effective for the removal of organic micropollutants and biological activities from sewage sludge?. Water Res. 102, 211-220. https://doi.org/10.1016/j.watres.2016. 06.025 .

Guerra, P., Kleywegt, S., Payne, M., Svoboda, M.L., Lee, H.-B., Reiner, E., Kolic, T., Metcalfe, C., Smyth, S.A., 2015. Occurrence and fate of trace contaminants during aerobic and anaerobic sludge digestion and dewatering. J. Environ. Qual. 44, 1193-1200. https://doi.org/10.2134/jeq2015.01.0010.

Herrmann, C., Kalita, N., Wall, D., Xia, A., Murphy, J.D., 2016. Optimised biogas production from microalgae through co-digestion with carbon-rich co-substrates. Bioresour. Technol. 214, 328-337. https://doi.org/10.1016/j.biortech.2016.04.119.

Hlavínek, P., Stř́iteský, L., Pešoutová, R., Houdková, L., 2016. Biogas production from algal biomass from municipal wastewater treatment. Waste Biomass Valoriz. 7 , 747-752. https://doi.org/10.1007/s12649-016-9488-2.

Iyovo, G.D., Du, G., Chen, J., 2010. Sustainable bioenergy bioprocessing: biomethane production, digestate as biofertilizer and as supplemental feed in algae cultivation to promote algae biofuel commercialization. J. Microb. Biochem. Technol. 02, 100-106. https://doi.org/10.4172/1948-5948.1000032.

Jimenez, J., Vedrenne, F., Denis, C., Mottet, A., Déléris, S., Steyer, J.-P., Cacho Rivero, J.A., 2013. A statistical comparison of protein and carbohydrate characterisation methodology applied on sewage sludge samples. Water Res. 47, 1751-1762. https://doi.org/10.1016/j.watres.2012.11.052.

Kupper, T., Berset, J.D., Etter-Holzer, R., Furrer, R., Tarradellas, J., 2004 Concentrations and specific loads of polycyclic musks in sewage sludge originating from a monitoring network in Switzerland. Chemosphere 54, 1111-1120. https://doi.org/ 10.1016/j.chemosphere.2003.09.023.

Kupper, T., Plagellat, C., Brändli, R.C., de Alencastro, L.F., Grandjean, D., Tarradellas, J., 2006. Fate and removal of polycyclic musks, UV filters and biocides during wastewater treatment. Water Res. 40, 2603-2612. https://doi.org/10.1016/j.watres. 2006.04.012

Macherius, A., Eggen, T., Lorenz, W.G., Reemtsma, T., Winkler, U., Moeder, M., 2012. Uptake of galaxolide, tonalide, and triclosan by carrot, barley, and meadow fescue plants. J. Agric. Food Chem. 60, 7785-7791. https://doi.org/10.1021/ jf301917q.

Magdalena, J., Ballesteros, M., González-Fernandez, C., 2018. Efficient anaerobic digestion of microalgae biomass: proteins as a key macromolecule. Molecules 23, 1098. https://doi.org/10.3390/molecules23051098.

Mahdy, A., Mendez, L., Ballesteros, M., González-Fernández, C., 2014. Autohydrolysis and alkaline pretreatment effect on Chlorella vulgaris and Scenedesmus sp. methane production. Energy 78, 48-52. https://doi.org/10.1016/j.energy.2014.05. 052 .

Mahdy, A., Mendez, L., Ballesteros, M., González-Fernández, C., 2015. Algaculture integration in conventional wastewater treatment plants: anaerobic digestion comparison of primary and secondary sludge with microalgae biomass. Bioresour. Technol. 184, 236-244. https://doi.org/10.1016/j.biortech.2014.09.145.

Mata-Alvarez, J., Dosta, J., Romero-Güiza, M.S., Fonoll, X., Peces, M., Astals, S., 2014. A critical review on anaerobic co-digestion achievements between 2010 and 2013. Renew. Sust. Energ. Rev. 36, 412-427. https://doi.org/10.1016/j.rser.2014. 04.039.

Matamoros, V., Nguyen, L.X., Arias, C.A., Nielsen, S., Laugen, M.M., Brix, H., 2012. Musk fragrances, DEHP and heavy metals in a 20 years old sludge treatment reed bed system. Water Res. 46, 3889-3896. https://doi.org/10.1016/j.watres.2012.04. 027.

Matamoros, V., Gutiérrez, R., Ferrer, I., García, J., Bayona, J.M., 2015. Capability of microalgae-based wastewater treatment systems to remove emerging organic contaminants: a pilot-scale study. J. Hazard. Mater. 288, 34-42. https://doi.org/10. 1016/j.jhazmat.2015.02.002.

Mussgnug, J.H., Klassen, V., Schlüter, A., Kruse, O., 2010. Microalgae as substrates for fermentative biogas production in a combined biorefinery concept. J. Biotechnol. 150, 51-56. https://doi.org/10.1016/j.jbiotec.2010.07.030.

Neumann, P., Torres, A., Fermoso, F.G., Borja, R., Jeison, D., 2015. Anaerobic co-digestion of lipid-spent microalgae with waste activated sludge and glycerol in batch mode. Int. Biodeterior. Biodegrad. https://doi.org/10.1016/j.ibiod.2015.01.020.

Olsson, J., Feng, X.M., Ascue, J., Gentili, F.G., Shabiimam, M.A., Nehrenheim, E., Thorin, E., 2014. Co-digestion of cultivated microalgae and sewage sludge from 
municipal waste water treatment. Bioresour. Technol. 171, 203-210. https://doi. org/10.1016/j.biortech.2014.08.069.

Palmer, C.M., 1962. Algas en los abastecimientos de agua. Manual ilustrado acerca de la identificación, importancia y control de las algas en los abastecimientos de agua Editorial Interamericana, México.

Passos, F., Ferrer, I., 2014. Microalgae conversion to biogas: thermal pretreatment contribution on net energy production. Environ. Sci. Technol. 48, 7171-7178. https:// doi.org/10.1021/es500982v

Passos, F., Ferrer, I., 2015. Influence of hydrothermal pretreatment on microalgal biomass anaerobic digestion and bioenergy production. Water Res. 68, 364-373. https://doi.org/10.1016/j.watres.2014.10.015.

Passos, F., Gutiérrez, R., Brockmann, D., Steyer, J.-P., García, J., Ferrer, I., 2015. Microalgae production in wastewater treatment systems, anaerobic digestion and modelling using ADM1. Algal Res. 10, 55-63. https://doi.org/10.1016/j.algal. 2015.04.008.

Passos, F., Gutiérrez, R., Uggetti, E., Garfí, M., García, J., Ferrer, I., 2017. Towards energy neutral microalgae-based wastewater treatment plants. Algal Res. 28, 235-243. https://doi.org/10.1016/j.algal.2017.11.006.

Rajagopal, R., Massé, D.I., Singh, G., 2013. A critical review on inhibition of anaerobic digestion process by excess ammonia. Bioresour. Technol. 143, 632-641. https://doi.org/10.1016/j.biortech.2013.06.030.

Safi, C., Zebib, B., Merah, O., Pontalier, P.-Y., Vaca-Garcia, C., 2014. Morphology, composition, production, processing and applications of Chlorella vulgaris: a review. Renew. Sust. Energ. Rev. 35, 265-278. https://doi.org/10.1016/j.rser.2014 04.007.

Samson, R., LeDuy, A., 1983. Improved performance of anaerobic digestion of Spirulina maxima algal biomass by addition of carbon-rich wastes. Biotechnol. Lett. 5, 677-682. https://doi.org/10.1007/BF01386361.

Schaider, L.A., Rodgers, K.M., Rudel, R.A., 2017. Review of organic wastewater compound concentrations and removal in onsite wastewater treatment systems. Environ. Sci. Technol. 51, 7304-7317. https://doi.org/10.1021/acs.est.6b04778.
Schwede, S., Kowalczyk, A., Gerber, M., Span, R., 2013. Anaerobic co-digestion of the marine microalga Nannochloropsis salina with energy crops. Bioresour. Technol. 148, 428-435. https://doi.org/10.1016/j.biortech.2013.08.157.

Schwede, S., Rehman, Z.-U., Gerber, M., Theiss, C., Span, R., 2013. Effects of thermal pretreatment on anaerobic digestion of Nannochloropsis salina biomass. Bioresour. Technol. 143, 505-511. https://doi.org/10.1016/j.biortech.2013.06.043.

Sialve, B., Bernet, N., Bernard, O., 2009. Anaerobic digestion of microalgae as a necessary step to make microalgal biodiesel sustainable. Biotechnol. Adv. 27, 409-416. https://doi.org/10.1016/j.biotechadv.2009.03.001.

Solé-Bundó, M., Cucina, M., Folch, M., Tàpias, J., Gigliotti, G., Garfí, M., Ferrer, I., 2017. Assessing the agricultural reuse of the digestate from microalgae anaerobic digestion and co-digestion with sewage sludge. Sci. Total Environ. 586, 1-9. https: //doi.org/10.1016/j.scitotenv.2017.02.006

Solé-Bundó, M., Eskicioglu, C., Garfí, M., Carrère, H., Ferrer, I., 2017. Anaerobic co-digestion of microalgal biomass and wheat straw with and without thermo-alkaline pretreatment. Bioresour. Technol.https://doi.org/10.1016/j.biortech.2017.03. 151

Solé-Bundó, M., Salvadó, H., Passos, F., Garfi, M., Ferrer, I., 2018. Strategies to optimize microalgae conversion to biogas: co-digestion, pretreatment and hydraulic retention time. Molecules 23, https://doi.org/10.3390/molecules23092096.

Solorzano, L., 1969. Determination of ammonia in natural waters by the phenolhypochlorite method. Limnol. Oceanogr. 14, 799.

Thorin, E., Olsson, J., Schwede, S., Nehrenheim, E., 2017. Co-digestion of sewage sludge and microalgae - biogas production investigations. Appl. Energy https:// doi.org/10.1016/j.apenergy.2017.08.085

Tran, N.H., Reinhard, M., Gin, K.Y.-H., 2018. Occurrence and fate of emerging contaminants in municipal wastewater treatment plants from different geographical regions-a review. Water Res. 133, 182-207. https://doi.org/10.1016/j.watres.2017. 12.029 .

Yang, S., Hai, F.I., Price, W.E., McDonald, J., Khan, S.J., Nghiem, L.D., 2016. Occurrence of trace organic contaminants in wastewater sludge and their removals by anaerobic digestion. Bioresour. Technol. 210, 153-159. https://doi.org/10.1016/j. biortech.2015.12.080. 